OZ, Amós. Uma certa paz. Tradução de Paulo Geiger. São Paulo: Companhia das Letras, 2000. 393p.

\title{
O demônio nos pregou uma peça em Uma certa paz, de Amós $\mathrm{Oz}$
}

\author{
Cláudia Maia*
}

"Um dia um homem se levanta e muda de um lugar para outro. O que ele deixa atrás de si fica para trás e só lhe vê as costas." Assim o escritor israelense Amós Oz inicia seu romance Uma certa paz, publicado em 1982 e traduzido recentemente no Brasil pela Companhia das Letras. A narrativa tem como tema central a partida do jovem Ionatam Lifschitz do kibutz onde nascera e crescera. Os kibutzim são comunidades agrícolas judaicas que tiveram importante função na criação do estado de Israel e no fortalecimento de sua identidade cultural, tendo fornecido líderes intelectuais, políticos e militares ao movimento sionista. A formação dessas comunidades, denominadas de kibutzim apenas mais tarde, começou por volta de 1880, quando se deu a "primeira aliá" - a primeira imigração de judeus para a terra que constituiria, posteriormente, o Estado de Israel. A intenção desses primeiros imigrantes judeus era trabalhar com a lavoura, atividade que caracterizou tais comunidades durante um longo tempo. O primeiro kibutz foi criado em 1914 e, além do cultivo da terra, pregado nos assentamentos anteriores, possuía um importante cunho socialista, assim como os outros que foram se formando.

A narrativa de Amós Oz apresenta de perto a vida em um kibutz na década de 1960, sobretudo nos anos de 1965 e 1967, imediatamente anteriores à Guerra dos Seis Dias, da qual Israel saíra vitorioso. O olhar crítico do escritor sobre a vida no kibutz advém de sua própria experiência: Oz viveu por muitos anos em uma dessas comunidades e em Uma certa pazdescortina os diferentes pontos de vista de seus moradores, menos ou mais ligados ao ideal sionista. Ionatam Lifschitz é filho do líder do kibutz e está insatisfeito com sua vida monótona e seu casamento infeliz, por isso, decide partir para um lugar "onde talvez o tivessem esperando", "um lugar completamente diferente", "um lugar entre os lugares distantes onde tudo é possível e tudo pode acontecer" (p. 12). Contudo, sua partida é sempre adiada: um serviço por fazer, a cadela que adoece, a dificuldade de falar com a esposa. Apenas nas últimas páginas da primeira parte do livro é que Ionatam parte em busca de outra vida, atendendo a um desejo recôndito de sair de um lugar onde não se sente feliz, cujos ideais para ele não passam de uma ilusão.

Antes de decidir a realmente partir, Ionatam conhece Azaria Guitlin, um jovem desconhecido que chega ao kibutz a fim de viver uma vida em comunidade, socialista que é. Dono de discursos empolados, de grande disposição para ajudar e se assimilar e adepto à filosofia de Espinosa, Azaria parece o oposto de Ionatam e, quando este parte, assume sua mulher Rimona e sua casa, criando assim um estranho triângulo amoroso, que permanece até o fim da narrativa. Aos sonhos de Azaria, que ninguém sabe ao certo quem realmente é, contrapõe-se a desilusão de Ionatam, que por várias vezes apresenta àquele a crueldade da vida e da guerra em resposta às citações de Espinosa. Rimona, a esposa de Ionatam, está aparentemente alheia à realidade, a ponto de não ser compreendida pelos outros personagens, que a consideram esquisita ou mesmo louca. Contudo, é ela quem descreve com perspicácia os dois jovens: "que um fale só um pouco porque está triste de ser como todos e que o outro fale o tempo todo porque está triste de ser um pouco diferente. Eu os aceito." (p. 186).

O projeto de Ionatam de abandonar o kibutz arrasta-se de forma angustiante por toda a primeira parte do livro, intitulada "Inverno". No capítulo nono, o narrador retoma várias frases das primeiras páginas, em que se anuncia o desejo do jovem. Essa repetição como que reforça o cerne da narrativa, que não está na partida em si ou em suas consequências, mas na ansiedade por ela, uma ansiedade por mudança. A narrativa de Amós Oz se alimenta das experiências individuais no kibutz e apresenta o conflito entre gerações em um período de incertezas políticas. Iulek Lifschitz, pai de Ionatam e líder 
do kibutz, é um homem influente na política de Israel e que contribuiu muito, junto com sua geração, nas lutas para a formação do Estado judeu. Contudo, ainda que não pareça, também apresenta inquietações e questiona, nostalgicamente, o que teria dado errado para que vários dos jovens membros da comunidade se dispersassem do ideal sionista e da religião. A opinião de Iulek sobre a nova geração e sua incerteza quanto a uma guerra que se anuncia são assim resumidas: "Muitas pessoas diferentes e esquisitas [...] esforçando-se para parecer um povo. Para se exprimir da mesma maneira. E substituindo sem parar canções antigas por canções mais novas. Dando expressão oral e escrita a todo tipo de esperanças, queixas e saudades como se esse abundante palavreado tivesse a força de silenciar essa fraca voz interior: por quê, por que se arrefece assim o coração cansado?" (p. 125), pergunta que exprime a desilusão de muitos daqueles que lutaram e ainda lutam pela paz em Israel.

Tal arrefecimento também é apresentado na longa carta que Iulek escreve a Levi Eshkol, primeiroministro de Israel na época em que é ambientada a narrativa de Oz. Nessa carta, Iulek confessa suas inquietações mais íntimas e seus temores quanto ao futuro de Israel e fala dos maus ventos que sopram no país e que parecem querer destruir tudo o que a sua geração conquistara: "É a ruína dos corações, eu digo. Na cidade. Nas colônias agrícolas. No kibutz. E especialmente, é claro, na juventude. O demônio nos pregou uma peça. Como uma peste adormecida, trouxemos conosco os vírus da diáspora, de lá para cá, e agora, ante nossos olhos, cresce e floresce aqui uma nova diáspora." (p. 170-171)

Para Iulek, o que falta à juventude, inclusive a seu filho, é a centelha, a chama judaica que incendiou sua geração. Contrário à posição do filho e de outros jovens, com seu caráter muitas vezes opressivo, Iulek questiona os ideais de liberdade da nova geração. Outro personagem, o músico Srulik, que substitui Iulek na liderança do kibutz, quando este se apresenta bastante doente, também reflete sobre esses jovens que estão "sempre envoltos em uma insólita tristeza. Como se fossem de outra tribo ou de um povo estranho" (p. 241). Contudo, diferente de Iulek, que não se conforma com o novo espírito que assola o kibutz, Srulik procura compreender as distintas vozes que ali habitam, registrando suas percepções no relatório que escreve quase todas as noites, e que toma muitas páginas da segunda parte do livro, intitulada "Primavera".

O romance de Oz trata, portanto, do fato de estar dentro ou fora de um determinado lugar, de uma determinada terra. As leituras de Srulik sobre a perambulação dos pássaros, frequentemente citadas em seu diário, ilustra suas reflexões sobre a navegação muitas vezes sem sentido que realizam os pássaros e também os homens, uma navegação sem sentido, mas muitas vezes necessária. Uma certa pazé, ainda, um romance sobre a solidão e a dor e sobre os diferentes modos de lidar com esses sentimentos. Oz apresenta uma visão nada idealizada de Israel, revelando vários aspectos de sua existência sempre problemática, em que cada um encontra sua maneira de seguir vivendo e lutar contra seus demônios, até que chegue o "descanso correto".

\footnotetext{
* Claudia Maia é Doutoranda em Letras: Literatura Comparada pela UFMG.
} 